\title{
Increased Mucification Present
}

National Cancer Institute

\section{Source}

National Cancer Institute. Increased Mucification Present. NCI Thesaurus. Code C129004.

A finding indicating an increase in the numbers of epithelial cells that have been transformed into mucus-secreting cells. This does not include the normal increase in mucification seen in the estrous cycle. 